CASE STUDY

\title{
Three Heads are Better Than One: Students, Faculty, and Educational Developers as Co-Developers of Science Curriculum
}

*Lori Goff and Kris Knorr, Paul R. MacPherson Institute for Leadership, Innovation, and Excellence in Teaching, McMaster University, Canada

Contact: Igoff@mcmaster.ca

\section{ABSTRACT}

Curriculum planning should be a shared responsibility that involves students. To encourage higher education students to actively participate in their own education, we believe in the idea of engaging students as partners in learning and teaching. We have developed an Applied Curriculum Design in Science course at McMaster University that is aimed at engaging students as co-creators of curriculum. In this course, upper-year students form partnerships with faculty and educational developers and work in groups to co-create learning modules that become key components of a foundational Science course offered to first-year students. We present a scholarly exploration of our rationale for the course, the implementation and critical analysis of the initiative, and ideas for sustaining the co-created pedagogical approaches and continued student engagement in co-creating components of the curriculum.

\section{KEYWORDS}

Students as Partners, co-creators, curriculum, learning modules, educational development

Academics routinely engage in collaboration and peer review of one another's work. Why is it, then, that we tend not to take a similar approach to collaborating with students on issues pertaining to their learning in higher education? Sometimes, students are involved as representatives on various university committees; however, this type of tokenistic engagement does little to provide students with opportunities to significantly influence, develop, or shape their learning experiences. Academic staff, referred to as faculty for the remainder of this paper, often have the power to make curriculum decisions; students are consulted less often about the curricula they experience as learners than employers and other stakeholders during the curriculum design process (Bovill, Bulley, \& Morss, 2011). 
One way to encourage students to participate more actively in their own education is to engage them as partners in learning and teaching (see for example, Bovill, Cook-Sather, \& Felten, 2011; Healey, Flint, \& Harrington, 2014; Mercer-Mapstone et al., 2017). The Policy Statement on Higher Education published by the Welsh Government (2013) states that, "true partnership relies upon an environment where the priorities, content, and direction of the learning experience are all set by students and staff in partnership" (p. 21). Such partnerships offer a sophisticated and effective process of engaging students in teaching and learning issues and initiatives in higher education, where both students and faculty stand to gain from developing a learning and working relationship together. As Healey et al. (2014) argue, these types of partnerships offer a great possibility for genuine transformational learning experiences, not only for students, but for all involved, including staff and faculty.

An exciting but rather under-explored partnership opportunity involves engaging students as co-creators of curriculum (Bovill, 2013). This idea is not new, as evidence of calls for such partnerships are rooted in Dewey's arguments for democratic school environments and progressive education. Many others have since continued with this idea and argued that curriculum planning be a shared responsibility that involves students (Giroux, Penna, \& Pinar, 1981; Rogers \& Freiberg, 1969; Shor, 1992).

Catherine Bovill, Peter Felten, Beth Marquis, and their colleagues have become recent advocates of engaging students as co-creators of the broader concepts of curriculum. Through various case studies and research projects, they have identified many benefits for students and faculty that come from engaging students as curriculum design partners, including deeper understandings of learning processes, enhanced engagement, increased motivation and enthusiasm, and stronger relationships between students and faculty (Bovill, 2014; Bovill et al., 2011; Bovill, Cook-Sather, Felten, Millard, \& Moore-Cherry, 2016; Bovill, Morss, \& Bulley, 2008; Marquis et al., 2017). These cases make a strong argument that faculty need to go beyond the tradition of simply consulting students or asking students for feedback, and rather engage them as full participants in designing teaching approaches, courses, and program curricula. Engaging students in this way will help in moving away from traditional hierarchical models of expertise and will help in achieving a radical collegiality where students are, as Fielding coined, "agents in the process of transformative learning" (Fielding, 1999, p. 22).

The process of transformative learning through co-creation of curriculum does not come without challenges. Challenges often involve faculty resistance to co-creation, navigating institutional barriers, and establishing inclusive co-creation approaches (Bovill et al., 2016).

In this paper, we present a case study of a program that actively engages students in the co-creation of program-level curricula using approaches that aim to minimize the challenges presented from other cases and increase the sustainability of the co-created pedagogical approaches. The intention of this paper is to describe a particular case at McMaster University where students, faculty, and educational developers worked in partnership to develop science curriculum, with a focus on educational developers' initial perspectives on successes and challenges. A subsequent research paper is in preparation to critically analyze the three perspectives (Knorr, Goff, \& Puri, manuscript in preparation). 


\section{CASE DESCRIPTION: APPLIED CURRICULUM DESIGN IN SCIENCE}

Enhancing the first-year student experience within the Faculty of Science at McMaster University became an important theme that arose in the early 2010s. In response, a committee was established by the Associate Dean of Science to better understand student experiences and to develop a program to engage and motivate first-year students across a variety of science disciplines.

\section{Conceptualizing a new foundational science curriculum}

The curriculum committee included the Associate and Assistant Deans of Science responsible for undergraduate studies, faculty members from each of the departments within the Faculty, academic support staff, two students, and two educational developers from the teaching and learning institute. From the outset, there was a strong desire to involve students in developing a course that would benefit students transitioning into first-year Science. The curriculum committee began by surveying upper-level Science students $(n=324)$ to identify their perspectives, needs, and satisfaction with their transition to university. The students on the curriculum committee were asked to gather additional feedback from their peers through the science student societies. The student representatives formed a sub-committee with two faculty members and two educational developers to articulate a course concept that was aimed at meeting the goals the larger committee had discussed. The new first-year course was conceptualized on the basis of four fundamental components that emerged from the data collected:

- A lecture series. Engaging face-to-face 50-minute lectures in the style of TED-talks were developed by each of the eleven departments within the Faculty because students were interested in exploring various disciplines in science. The goal of these lectures was to introduce students to the most interesting facets of the discipline, including current and exciting research, as well as opportunities for further study and future career prospects.

- A series of weeklong learning modules. In response to students' desire to have smallcohort learning opportunities in their first year, tutorials of $\sim 25$ students were conceived in which students would engage in miniature research investigations (MRIs) designed to expose, engage, and motivate student interests in scientific-based explorations from a wide-variety of scientific disciplines. The intention was to provide students opportunities to develop and hone skills pertaining to the scientific method. Each module, for example, could focus on an aspect of one of the following: stating a hypothesis, reviewing literature, designing an experiment, collecting and analyzing data, or presenting findings.

- A learning portfolio. A learning portfolio tool was proposed to allow students to document their own learning goals, reflect upon their learning experiences and skills development, and become aware of their future professional or academic goals.

- Support from peer mentors. The committee also proposed to include peer mentors as a key element of the course who could act as an important resource for first-year students. Students would complete their learning modules together with the support and encouragement of upper-level peer mentors; peer mentors in turn would share their experiences that helped them through the transition to university. 
Each of the four components was developed with varying levels of student partnership and engagement. Most lectures tapped into student input and feedback, and several lectures invited students to share and showcase their experiences and voices. A first-year student partner designed the learning portfolio component based on a combination of his extensive literature reviews, consultations with students, and his own experiences. Two students, one third-year Science student, and one intern from a neighbouring university's teacher education program conducted thorough literature reviews and environmental scans and then worked in tandem to design the peer mentoring component for the first-year course. However, it was the development of the learning module series that engaged students as partners in a new and exciting manner.

\section{Creating learning modules for the first-year Science curriculum}

Once the course concept was approved, members of the curriculum committee discussed approaches in actually designing and developing each of the components, with a keen interest in finding new ways in which we could partner across roles. Faculty members bring a perspective on what disciplinary content and skills students need to know, while students have a perspective on what they find to be meaningful and engaging learning opportunities. Educational developers can help bring these two perspectives together through good practice in course and curriculum design. To enable this cross-role partnership work in the development of components for the course, we, the authors and educational developers with a science background, designed a third-year course in Applied Curriculum Design in Science.

Third- and fourth-year Science students were invited to apply for this for-credit course. Course content in the early weeks was focused on science education, instructional design, and course design principles. Students brainstormed lists of topics that they found most interesting about the many disciplines within science. They also collectively identified the many skills that they felt they would have most benefited from learning and practicing in their first year of university. Students divided into 10 small groups and identified common scientific topics of interest and particular skills that they wanted to help first-year students develop. Each student group was connected with two faculty members who served as disciplinary experts and with the two educational developers who served as instructors for the course. We believe that when these three roles work together in partnership, curriculum development processes are optimized.

The deliverable for the Applied Curriculum Design in Science course was a stand-alone, one-week learning module that aimed to engage first-year students in a miniature research investigation on a topic they selected. Together with the disciplinary experts and the educational developers, the curriculum design students articulated and refined the intended learning outcomes of their module, prepared module outlines and all necessary resources, and created an assessment that would provide first-year students with feedback on their skill development. Students showcased their learning modules at a symposium and revised them based on feedback from the Associate Dean, disciplinary experts, other faculty and support staff, and many Science students.

In the first offering of Applied Curriculum Design in Science, 10 learning modules were created by 10 groups that involved student-faculty-educational-developer partnerships. Because it was not possible to incorporate all 10 modules into the first-year course, a team of

Goff, L., \& Knorr, K. (2018). Three heads are better than one: Students, faculty, and educational 
three students and one faculty member subsequently selected six of the 10 learning modules to refine (for consistency) and include in the initial offering of the new first-year foundational science course. Modules were selected on the basis of representing a breadth of disciplines and skills, as well as the feasibility of implementation. The other modules went into a bank for possible use in the future.

\section{IMPACT AND FUTURE PROMISE}

As a result of offering this course, we have identified approaches that may be beneficial to those interested in partnering with students in curriculum design to minimize challenges, enhance sustainability, and to continue to engage students in the co-design process.

\section{Minimizing challenges}

Engaging students as co-creators of curriculum does not come without challenges. Challenges often involve faculty resistance, institutional barriers, and inclusive and sustainable approaches to co-creation (Bovill et al., 2016; Bovill, Cook-Sather, \& Felten, 2011).

While there were many benefits in co-creating a series of learning modules, how we experienced challenges is worth mentioning in relation to what has been reported in the literature. Bovill et al. (2016) reported that resistance to co-creation, often from faculty but also from students, can be a challenge. In our case, students who were open to co-creating curriculum self-selected into the Applied Curriculum Design in Science course by applying and enrolling. Some faculty certainly experienced more resistance than others -in some cases because of the added workload in guiding students as disciplinary experts and in some cases because they felt their discipline was not being emphasized adequately. While these are indeed challenges, we hope that by offering the course every second or third year that we can minimize the amount of added work and increase the variety and availability of learning modules within each of the disciplines. Having students work closely with educational developers as instructors alleviated much concern about students' pedagogical expertise that both students and faculty may have otherwise faced.

As Bovill et al. (2016) described, we discovered that an orientation towards co-creation was indeed novel at our institution, as the idea of co-creation falls outside of traditional roles. However, rather than encountering barriers, we were very fortunate that the pilot offering of Applied Curriculum Design in Science garnered significant support and encouragement through our ongoing consultation, networking, and engagement with the university President, the Provost, the Vice-Provost (Teaching \& Learning), and the Dean and Associate Dean within the Faculty of Science.

Establishing a balance between selection and inclusion is another potential challenge (Felten et al., 2013). Bovill and colleagues (2016) recommend that whether all students are included or purposefully selected, faculty should consider whose voices are heard and whose are not, whose participation is invited and whose is not, and what the implications are for cocreation projects, the larger institutions of which they are a part and the individual and groups of participants involved (p. 9).

Many students enrolled in the Applied Curriculum Design in Science course who would not otherwise have been included in contributing to university curriculum; however, instructors 
will need to become more conscious of whose voices are not being included and how that might affect the outcomes of the co-created projects. One initial observation is that only students who had achieved a $75 \%$ average were admitted into the course, thus excluding students with lower grades. Perhaps students with lower grades may have additional insight into how modules might be designed to engage a broader range of first-year students and may be more knowledgeable about ways to engage students who struggle academically in their first year. Based on this observation, the authors (with additional colleagues) are presently conducting a research study to investigate whether incoming grades are an appropriate indicator of success in student partnership roles.

\section{Enhancing sustainability}

The structure of Applied Curriculum Design in Science, now offered every two to three years, allows the Faculty of Science to engage students as co-creators of curriculum and to build a repository of student-designed learning modules from which to draw when selecting the learning modules for the first-year foundations Science course. By integrating the Applied Curriculum Design in Science course into the regular course offerings within the Faculty of Science in a sustainable manner, it benefits upper-year students who wish to contribute their voices and ideas for future students, first-year students who become engaged in science by completing student-designed learning modules, and faculty who will have an ever-growing bank of current, faculty-endorsed learning modules from which to draw.

Questions have been raised about the sustainability of co-created pedagogical approaches, which can enhance student ownership of learning in one year but might call for redesign by the next cohort of students to ensure the same depth of learning (Bovill, Cook-Sather, \& Felten, 2011). It is important to recognize that one cohort of student curriculum designers cannot fully represent the learning needs of all future students. We expect that repeating this design process in subsequent iterations of the Applied Curriculum Design in Science course will allow student curriculum designers to consider the changing learning needs of different cohorts of incoming Science students.

\section{Continued engagement}

Engaging students as partners in designing curriculum through the Applied Curriculum Design in Science course has gained support and recognition, not only within our institution, but beyond. Efforts to create student-faculty partnerships have not stopped with the introduction of this course. Indeed, faculty and educational developers have continued to partner with students in presenting this idea at several national and international conferences (Goff \& Knorr, 2014; Goff, Knorr, Tang, Ndoja, \& Mahiri, 2014; Knorr, Goff, Ashfaq, Garasia, \& Ahmad, 2014; Symons et al., 2015). Some students continued to partner with educational developers on teaching and learning initiatives well beyond the completion of the Applied Curriculum Design in Science course and even beyond their undergraduate studies at McMaster University. Upon graduation, other curriculum design students continued to work on encouraging students to become partners in teaching and learning initiatives by conceptualizing and developing ideas and programs at McMaster and at other universities. 
While a growing body of literature suggests that partnerships can impact students, staff, and faculty in deepening learning and engagement and in adopting scholarly approaches to learning and teaching (Bovill et al., 2016), the long-term impact of engaging and partnering with students is not clear and would be worth studying. However, as we reported in our study of student perspectives' of the new course (Cockcroft et al., 2016), 92\% of students registered in the initial offering of the foundational Science course indicated that they would take the course again, and $98 \%$ would recommend the course to other incoming first-year students (Cockcroft et al., 2016). It would be important to get a better understanding of how these partnership experiences may have influenced the perspectives and future approaches or directions of faculty, staff, and students in the long term. It might also be interesting to study the impact and sustainability of the outcomes or deliverables that were developed within these partnerships.

We recognize that there are challenges associated with having students and faculty form partnerships to co-create curriculum. We have discussed some of these challenges in this paper; however, our experiences lead us to believe that there is much more to uncover. As such, we are engaging in ongoing research to explore the benefits and challenges of designing curriculum in partnership. At this time, though, we have found that through our experiences in offering a formal course that engages students, faculty, and educational developers as cocreators of curriculum, such partnerships can work towards challenging traditional facultystudent boundaries, while simultaneously respecting the experiential expertise of students, disciplinary expertise of faculty, and curricular expertise of educational developers. Three heads are better than one.

\section{ACKNOWLEDGEMENTS}

The authors would like to acknowledge the valuable contributions of the first Science 3M03 class; the MacPherson Student Partners Program; student partners Varun Puri, Jason Woo, Crystal Rosbrook, Iqra Ashfaq, Katie Maloney, and Sophiya Garasia; and faculty and administrators Dr. Mic Farquharson, Dr. Sarah Symons, Dr. Kim Dej, and Sarah Robinson.

\section{NOTE ON CONTRIBUTORS}

Lori Goff is the Associate Director of Program and Educational Development at the Paul. R. MacPherson Institute for Leadership, Innovation, and Excellence in Teaching at McMaster University, Hamilton, Canada. Lori has previously conducted research and program evaluations on peer mentoring programs and is currently interested in how partnering with students can enhance teaching and learning, curriculum development and review, educational leadership, and academic culture.

Kris Knorr is the Area Lead for Faculty Development at the Paul R. MacPherson Institute for Leadership, Innovation, and Excellence in Teaching at McMaster University, Hamilton, Canada. Kris's research interests have involved investigating professional development needs of faculty/instructors, identity as scholarship of teaching and learning (SoTL) researchers, and student partnerships in post-secondary education. 


\section{REFERENCES}

Bovill, C. (2013). Students and staff co-creating curricula: An example of good practice in higher education? In E. Dunne \& D. Owen (Eds.), The student engagement handbook: Practice in higher education (pp. 461-476). Bingley: Emerald.

Bovill, C. (2014). An investigation of co-created curricula within higher education in the UK, Ireland and the USA. Innovations in Education and Teaching International, 51(1), 15-25. https://doi.org/10.1080/14703297.2013.770264

Bovill, C., Bulley, C. J., \& Morss, K. (2011). Engaging and empowering first-year students through curriculum design: Perspectives from the literature. Teaching in Higher Education, 16(2), 197-209. https://doi.org/10.1080/13562517.2010.515024

Bovill, C., Cook-Sather, A., \& Felten, P. (2011). Students as co-creators of teaching approaches, course design and curricula: Implications for academic developers. International Journal for Academic Development, 16(2), 133-145. https://doi.org/10.1080/1360144X.2011.568690

Bovill, C., Cook-Sather, A., Felten, P., Millard, L., \& Moore-Cherry, N. (2016). Addressing potential challenges in co-creating learning and teaching: Overcoming resistance, navigating institutional norms and ensuring inclusivity in student-staff partnerships. Higher Education, 71(2), 195-208. https://doi.org/10.1007/s10734-015-9896-4

Bovill, C., Morss, K., \& Bulley, C. (2008). Curriculum design for the first year: First year enhancement theme report. Glasgow: Quality Assurance Agency for Higher Education.

Cockcroft, R., Symons, S. L., Goff, L., Knorr, K., Robinson, S. J., van Wersch, G., Charney, D., \& Farquharson, M. J. (2016). New interdisciplinary science course for first-year Faculty of Science students: Overview and preliminary results from the pilot. Collected Essays on Learning and Teaching, 9, 43-68. https://doi.org/10.22329/celt.v9i0.4431

Felten, P., Bagg, J., Bumbry, M., Hill, J., Hornsby, K., Pratt, M., \& Weller, S. (2013). A call for expanding inclusive student engagement in SoTL. Teaching and Learning Inquiry, 1(2), 6374. https://doi.org/10.20343/teachlearninqu.1.2.63

Fielding, M. (1999, September). Radical collegiality: Affirming teaching as an inclusive professional practice. Paper presented at the British Educational Research Association Conference, Brighton, England.

Giroux, H.A., Penna, A. N., \& Pinar, W. F. (1981). Curriculum and instruction: Alternatives in education. Berkeley, California: McCutchan Publishing.

Goff, L. \& Knorr, K. (2014, June). How far can we go? Engaging university students in the construction of their education. Paper presented at the Society for Teaching and Learning in Higher Education Conference, Kingston, Ontario.

Goff, L., Knorr, K., Tang, B., Ndoja, S., \& Mahiri, K. (2014, May). Developing courses for students by students: Engaging students as co-creators of curricula. Paper presented at the Canadian Society for the Study of Higher Education Conference, St. Catharine's, Ontario.

Healey, M., Flint, A., \& Harrington, K. (2014). Engagement through partnership: Students as partners in learning and teaching in higher education. York: Higher Education Academy. https://www.heacademy.ac.uk/system/files/resources/engagement through_partnershi p.pdf

Goff, L., \& Knorr, K. (2018). Three heads are better than one: Students, faculty, and educational 119 
Knorr, K., Goff, L., \& Puri, V. (in preparation). A critical research analysis of shared curriculum design approaches among students, faculty, and educational developers.

Knorr, K., Goff, L., Ashfaq, I., Garasia, S., \& Ahmad, A. (2014, October). Engaging students as codesigners and curriculum developers for an introductory university course. Paper presented at the meeting of the International Society for the Scholarship of Teaching \& Learning, Quebec City, Quebec.

Marquis, E., Puri, V., Wan, S., Ahmad, A., Goff, L., Knorr, K., Vassileva, I., \& Woo, J. (2017). Navigating the threshold of student-staff partnerships: A case study from an Ontario teaching and learning institute. International Journal of Academic Development, 21(1), 415. https://doi.org/10.1080/1360144X.2015.1113538

Mercer-Mapstone, L., Dvorakova, S. L., Matthews, K. E., Abbot, S., Cheng, B., Felten, P., Knorr, K., Marquis, E., Shammas, R., \& Swaim, K. (2017). A systematic literature review of students as partners in higher education. International Journal for Students as Partners, 1(1). https://doi.org/10.15173/ijsap.v1i1.3119

Rogers, C., \& Freiberg, H. J. (1969). Freedom to learn (3rd ed.) New York: Macmillan Publishing. Shor, I. (1992). Empowering education: Critical teaching for social change. London: University of Chicago Press.

Symons, S. L., Charney, D., van Wersch, G., Knorr, K., Goff, L., Cockcroft, R., Farquharson, M. J., \& Robinson, S. J. (2015, June). New interdisciplinary science course for first-year Science students: Overview and results from the pilot. Paper presented at the Society for Teaching and Learning in Higher Education Conference, Vancouver, British Columbia.

Welsh Government (2013). Policy statement on higher education. Cardiff: Welsh Government. Retrieved from http:/wales.gov.uk/topics/educationandskills/highereducation/policy 